Z. Anal. Chem. 280, 223 (1976) - (C) by Springer-Verlag 1976

\title{
Extraction-Spectrophotometric Determination of Niobium in Steels using Sulphochlorophenol S and High-Molecular Amines
}

\author{
N. Ivanov ${ }^{1}$, R. Borissova ${ }^{1}$, and E. Veselinova ${ }^{2}$ \\ ${ }^{1}$ Dept. of Anal. Chem., Higher Inst. of Chem. Technol., Sofia \\ ${ }^{2}$ Inst. of Metallurgy, Sofia-Botunez, Bulgaria \\ Received July 21, 1975; revised November 20, 1975 \section{unter Verwendung von Sulfochlorphenol $S$ und hochmolekularen Aminen} \\ Extraktionsphotometrische Bestimmung von Niob in Stahl
}

Best. von Niob in Stahl; Spektralphotometrie; Sulfochlorphenol S

A procedure is recommended for the spectrophotometric determination of niobium in steels using sulphochlorophenol $\mathrm{S}$ as a reagent. For the decomposition of the sample a new method has been worked out making use of solid tartaric acid after slow treatment with $\mathrm{HCl}$ and $\mathrm{H}_{2} \mathrm{O}_{2}$. For the extraction of the complex formed several high-molecular amines have been studied, employing a concentration of $5-10 \%$ in butanol and a volume relation between aqueous and organic phases of $3: 1$. Best results were obtained with laurylamine and cetylamine, the latter being however more expensive. For $15 \mu \mathrm{g}$ of $\mathrm{Nb} 2 \mathrm{ml}$ of the reagent solution $(0.03 \%)$ are required. Maximum permissible concentration of steel is $1-$ $1.2 \mathrm{mg} / \mathrm{ml}$. The standard deviation has been found to be $3 \%$. Beer's law is obeyed up to $15 \mu \mathrm{g}$ of $\mathrm{Nb}$ in the aqueous phase. $\mathrm{Mn}, \mathrm{Cr}, \mathrm{Ni}, \mathrm{Co}, \mathrm{W}, \mathrm{Ti}, \mathrm{Si}$ and other foreign ions do not interfere. Optimum conditions are incorporated in the following working direction.

Procedure. Dissolve $0.25 \mathrm{~g}$ of the steel sample with $5 \mathrm{ml}$ of conc. $\mathrm{HCl}$, heat carefully on a sand bath adding every $2-3 \mathrm{~min}$ 1-2 drops of $\mathrm{H}_{2} \mathrm{O}_{2}$ until complete decomposition of the carbides, concentrate to about $3 \mathrm{ml}$, add $3 \mathrm{~g}$ of solid tartaric acid, $7 \mathrm{ml}$ of conc. $\mathrm{HCl}$ and boil softly for $5 \mathrm{~min}$. Cool, dilute to $50 \mathrm{ml}$, transfer a $5 \mathrm{ml}$ aliquot to a $25 \mathrm{ml}$ volumetric flask, add $1 \mathrm{ml}$ of $5 \%$ tartaric acid solution, $0.5 \mathrm{ml}$ of $10 \mathrm{M} \mathrm{HClO}_{4}$ and $2 \mathrm{ml}$ of $25 \% \mathrm{NH}_{2} \mathrm{OH} \cdot \mathrm{HCl}$ solution together with $3 \mathrm{ml}$ of water. Heat carefully on a sand bath until the solution becomes colourless. Then add $4 \mathrm{ml}$ of $5 \%$ tartaric acid solution, $0.5 \mathrm{ml}$ of $10 \mathrm{M} \mathrm{HClO}_{4}, 2 \mathrm{ml}$ of $0.03 \%$ sulphochlorophenol S solution and $1 \mathrm{ml}$ of water. Cool (after $10 \mathrm{~min}$ ), add $6.00 \mathrm{ml}$ of $2 \%$ laurylamine solution in $\mathrm{n}$-butanol, shake for 2-3 min, transfer after 15-20 min a part of the organic phase into a $1 \mathrm{~cm}$ wet cell and measure the absorbance at $660 \mathrm{~nm}$ against a blank prepared in the same way. Molar absorptivity is $180001 \cdot \mathrm{mol}^{-1} \cdot \mathrm{cm}^{-1}$.

Dr. N. Ivanov, Dept. of Anal. Chemistry, Higher Inst. of Chem. Technology, Sofia-56, Bulgaria 